\begin{tabular}{lrr} 
STUDIA ROMANICA & POSNANIENSIA \\
\hline UAM & Vol. $41 / 2$ & Poznań 2014
\end{tabular}

\title{
ZDZISŁAW HRYHOROWICZ
}

hryhor@amu.edu.pl

Uniwersytet im. Adama Mickiewicza, Poznań

\section{PE MARGINEA FENOMENULUI POLONEZ DE AVANGARDĂ ÎN LUMINA REVISTEI CONTIMPORANUL}

\begin{abstract}
Zdzisław Hryhorowicz, Pe marginea fenomenului polonez de avangardă în lumina revistei „Contimporanul” [Upon the Polish Vanguard Movement as Depicted by the Journal Contimporanul], Studia Romanica Posnaniensia, Adam Mickiewicz University Press, Poznań, vol. XLI/2: 2014, pp. 73-81. ISBN 978-83-232-2703-8. ISSN 0137-2475. eISSN 2084-4158. DOI: 10.7169/strop2014.412.006

The present article is meant to offer a view of the avant-garde movement initiated by the Romanian avant-garde journal Contimporanul at the beginning of last century with regard to the Polish echoes in its pages. Together with the artistic phenomena quoted by the editors of journal, in order to offer a complete range of data, we intend to present to the Romanian public an accurate image of the Polish literary and artistic phenomenon.
\end{abstract}

Keywords: the arts, avant-garde, literary group, modern

Revista Contimporanul (1922-1932), cea mai longevivă şi mai importantă dintre revistele avangardei interbelice româneşti, precum se ştie, promova şi asimila numeroase noile direcţii şi tendinţe emancipatoare (artistice, sociale, politice) din România şi din afara ei sub semnul unei internaţii intelectuale a spiritelor de avangardă, încercând să medieze „exportul” de ,artă nouă” autohtonă şi să intermedieze cunoaşterea reciprocă a avangardelor „periferice” (belgiană, cehoslovacă, maghiară, poloneză, română, sârbă etc.), în dorinţa de a depăşi astfel tradiţionalul complex periferic românesc. Se cuvine să afirmăm, şi nu credem să greşim prea mult, că, într-o perioadă când majoritatea artiştilor români (şi nu numai) priveau exclusiv către marile centre ale culturii europene, revista lui Ion Vinea şi Marcel Iancu a fost singura care a avut în vedere şi ceea ce se întâmpla în spațiile învecinate. Având o dimensiune literară extrem de importantă în anii '20 ai secolului XX în România, revista şi gruparea Contimporanul au avut şi o dimensiune extraliterară cel puţin la fel de importantă (arhitectură, artă vizuală şi decorativă, cinematografie, expoziţ̧i internaţionale, grafică, manifestări „sincretice”, pictură, teatru, dar şi politică). Ilustrând spiritul Art Déco al anilor '20, Contimporanul pledează şi pentru inovaţiile în materie de mobilier şi de scenografie, încercând să creeze „stilul epocii”. Deşi cu o audienţă relativ redusă, 
datorită expoziţiilor artistice, seratelor de poezie, muzică şi interpretare teatrală organizate de gruparea Contimporanul, în aşa fel ea a contribuit la promovarea şi asimilarea „spiritului nou” în numeroase domenii ale vieţii artistice româneşti, la educarea gustului de elită intelectuală şi artistică din România acelor vremuri, participând astfel la dorita „revoluţie a sensibilităţii” (A quand la révolution de la sensibilité, la vraie?), preconizată de Ion Vinea într-un antimanifest din revista Punct, intitulat semnificativ Vorbe goale (v. Mincu, 1983: 126).

În articolul de faţă nu ne propunem să reexaminăm elementele şi sursele doctrinare ale grupării şi ale revistei Contimporanul prin apelul la modelele de dinafara României şi la teoriile artei moderne pentru că există deja suficiente abordări în acest sens (vezi de ex. Pop, 1990; Duda, 1997; Bârna, 2003; Morar, 2005; Cernat, 2007). Contribuţia literară a Contimporanului a fost pe larg comentată şi analizată, găsindu-şi locul ei potrivit şi binemeritat în domeniul cercetărilor literare românești. Importantă şi mai puţin abordată ni se pare latura „promoţională” a revistei lui Ion Vinea şi Marcel Iancu care, mai presus de toate, a fost o panoramă sintetică a noilor idei artistice din anii '20 ai secolului trecut, ,un barometru - cum scrie Paul Cernat - al evoluţiei avangardismului european, dar şi o interfaţă între platforme artistice şi ideologice foarte diverse" (Cernat, 2007: 10): belgiană, în special cea valonă, cehoslovacă, maghiară, rusă, sârbă, slovenă şi „last but not least" polonă, mai ales primul val al mişcării de avangardă în Polonia din anii '20 ai veacului trecut.

Despre „ecourile poloneze” a mai pomenit şi Paul Cernat în istoria sa cu privire la revista Contimporanul (Cernat, 2007: 92-96), fără, însă, să abordeze mai profund miezul „revelaţiilor” aduse de redacţia Contimporanului din învecinata Polonie, ceea ce ni se pare, pe de o parte, un fapt a cărui semnificație trebuie recunoscută pe deplin, iar pe de alta, nu este de mirare superficiala relatare a fenomenului avangardist polonez de către revista respectivă a cărei pricină trebuie căutată, mai presus de toate, în vaga orientare în domeniul limbii polone din partea redacției Contimporanului. Acest fapt a dus, vrând nevrând, la multe lapsusuri lingvistice de tip ortografic şi onomastic în reproducerea românească a fenomenului polonez de avangardă.

Revistele româneşti de avangardă de la început de secol XX, în special revista Contimporanul, consemnează apariţii de reviste şi manifestări artistice poloneze nu atât din domeniul poeziei, cât, mai ales, din domeniul artelor plastice, sculpturii şi arhitecturii, fără, însă, a le aborda mai îndeaproape, mulţumindu-se doar, în majoritatea cazurilor, cu enumerarea unor exemple particulare ale fenomenului polonez. Or, ni se pare de cuviinţă să desfăşurăm mai pe larg particularitatea acestui tablou al mişcării novatoare poloneze, doar schițat de către redacţia Contimporanului, pentru a aduce la cunoştinţa publicului cititor românesc o panoramă mai completă a primelor mişcărilor avangardiste din Polonia începutului de secolul XX. 
Numărul 45 al Contimporanului, din aprilie 1924, semnalează revista Blok, fără a da însă denumirea ei completă - Czasopismo Awangardy Artystycznej [Revista Avangardei Artistice], publicată de o grupare avangardistă din Varşovia, denumită Blok Kubistów, Suprematystów i Konstruktywistów [Bloc al Cubiştilor, Suprematiş̧tilor şi Constructiviştilor], din anii 1923-1926, redactată de către Henryk Stażewski (1894-1988), Teresa Żarnowerówna (1895-1950), Mieczysław Szczuka (1898-1927) şi Edmund Miller, unde au publicat - alături de autori polonezi - şi Filippo Tommaso Marinetti, Theo van Doesburg, Kurt Schwitters şi Herwarth Walden.

Revista Blok. Czasopismo Awangardy Artystycznej, în afara interesului acordat artelor plastice şi teoriei artelor în general, prezenta topurile din domeniul muzicii contemporane, literaturii şi teatrului. Primul număr al revistei Blok, apărut în anul 1924 (menţionat imediat după apariţie, chiar în acelaşi an, de către Contimporanul, ceea ce dovedeşte o bună orientare a colectivului revistei româneşti în materie), doar de patru pagini, cu reproduceri, în special, şi puţin text, foarte restrâns, nesemnat, cu caracter de manifest. În 1924, au mai apărut opt numere, inclusiv trei numere duble, şi la 10 aprilie 1925 apare al zecelea număr al revistei Blok consacrat în întregime Expoziţiei Internaţionale de Artă Decorativă din Paris, cu articolul Este oare o artă decorativă prezentând ideologia artistică a avangardei constructiviste poloneze. La 1 martie 1926, apare ultimul număr al Blok-ului, al unsprezecelea, despre arhitectură, cu ocazia Primei Expoziţii Internaţionale de Arhitectură Modernă, desfăşurată la Varşovia. Conţinutul revistei 1-au constituit reproducţii şi texte elaborate de participanţii respectivei expoziţii (pentru detalii, v. Baranowicz, 1979: 262).

Din gruparea Blok Kubistów, Suprematystów i Konstruktywistów, care s-a constituit în urma evenimentului artistic de la Vilnius, numit Expoziţia de Artă Nouă din 1923 - temelia constructivismului polonez, au făcut parte, printre alţii, Mieczysław Szczuka, Jan Golus (1895-1964), Katarzyna Kobro-Strzemińska (18981951), Władysław Strzemiński (1893-1952), Teresa Żarnowerówna, Henryk Berlewi (1894-1967), Henryk Stażewski, Maria Nicz-Borowiakowa (1896-1944), Aleksander Rafałowski (1894-1981), Maria Puciatycka, Witold Kajruksztis (18901961), Karol Kryński (1900-1944) i Mieczysław Szulc - artişti plastici, sculptori, pictori, arhitecţi, dintre care un loc de frunte 1-a avut Władysław Strzemiński teoretician al artelor, pictor, iniţiator al avangardei constructiviste din Polonia anilor '20 şi '30, autorul teoriei unismului (culoarea şi forma, contopindu-se, fac o unitate bine închegată în ramele unui tablou).

În anul 1926 gruparea Blok s-a destrămat, ca urmare a unor neînţelegeri ideologice ale membrilor grupării respective, dintre care au plecat Władysław Strzemiński, Katarzyna Kobro-Strzemińska şi Henryk Stażewski pentru a forma o nouă mişcare avangardistă de arhitecţi sub denumirea Praesens (1926-1930), 
apelând la renunțarea la formele tradiţionale din arhitectură şi artele plastice. De remarcat sunt afinităţile ideologice ale grupării poloneze Praesens cu linia ideologică a Bauhaus-ului din Weimar, a neerlandezului De Stijl şi a Şcolii Superioare de Artă din Moscova (Vhutiemas).

Praesens, încheindu-şi activitatea, s-a transformat, în 1931, într-o grupare a.r. (Artyści Rewolucyjni lub Awangarda Rzeczywista [Artişti Revoluţionari sau Avangarda Reală]), cu Władysław Strzemiński, Katarzyna Kobro-Strzemińska, Henryk Stażewski - arhitecţi, artişti plastici, cu Julian Przyboś (1901-1970) - poet şi Karol Hiller (1891-1939) - pictor, fotograf şi grafician.

În numărul 48 al Contimporanului, din octombrie 1924, găsim, pe o întreagă pagină, un articol semnat de Mieczysław Szczuka, datat „Varşovia 1924”, intitulat Mișcarea artistică în Polonia, fără nicio remarcă din partea redacţiei dacă este o traducere a unui articol din polonă sau este un text scris de Szczuka direct în română.

Mieczysław Szczuka, artist plastic, reprezentantul constructivismului şi productivismului polonez (arta, legată de realitatea materială, creând un nou proletar-artist îi acordă producţiei industriale statutul de artă), a fost şi directorul revistei Dźwignia [Levier], inspirată din ideologia Partidului Comunist Polonez, al cărui prim număr, din martie 1927, reproduce un fel de manifest al redacţiei (al lui Szczuka însuşi) după care revista va grupa oameni de cultură (literaţi, artişti plastici etc.) activând pentru un proletariat contemporan în spiritul marxismului (Baranowicz, 1979: 149). Până la moartea artistului în ziua de 13 august 1927 (escaladând pantă sudică a muntelui Zamarła Turnia din lanţul munţilor Tatra), au mai apărut patru numere ale revistei Dźwignia.

Numărul 5 al revistei Dźwignia va fi prezentat de Contimporanul în martie 1928 (numărul 77), fiind totodată şi un necrolog al recent decedatului Mieczysław Szczuka: „Dźwignia 5 este în întregime închinată lui M. Szczuca, decedat în august 1927, un vajnic luptător al modernismului pe tărâmul arhitecturii şi al afişului, organizator şi colaborator asiduu, alături de T. Zarnowerowna, al revistei Blok, ceea ce a însemnat începutul mişcărei moderne în Polonia" (Contimporanul, 1928, III: 77).

Articolul Mişcarea artistică în Polonia, apărut în Contimporanul, este - cum scrie Cernat - „un portret fizionomic şi o istorie comprimată a artei moderne poloneze, sistematizată pe puncte" (Cernat, 2007: 92). După autorul acestui articol, mişcarea artistică poloneză a anilor '20 este sensibilă, hiperdezvoltată, lipsită de probleme pur formale, artiştii activând în special în două centre intelectuale poloneze, Cracovia şi Varşovia, unde s-au format grupările moderniste numite „formiste", reprezentând futurismul şi expresionismul (Cracovia) şi formula cubism expresionism (Varşovia), care - deşi îşi pierd terenul după 1922, în opinia lui Szczuka, au oferit, totuşi, societăţii poloneze multe „invenţiuni”, explicând „în 
public şi pentru prima oară problemele formale de artă" (Contimporanul, 1924, X: 48). În mod neaşteptat, Szczuka trece în articolul respectiv la a caracteriza gruparea Blok de la care, cum susţine autorul, „a pornit semnalul: munca metodică, intelectuală, colectivă [...] a preocupărilor programului nostru [care este $]^{1}$ indivizibilitatea problemelor de artă şi a problemelor sociale. Ne-am manifestat pentru stânga radicală, în mişcarea socială" (Contimporanul, 1924, X: 48).

Despre revista grupării Blok (Blok. Czasopismo Awangardy Artystycznej, numer 6-7), se menţionează la rubrica „Cărţi şi reviste” a numărului următor: „,e dernier numéro témoigne de la richesse de l'art plastique moderne polonais" (Contimporanul, 1924, XI: 49), subliniind totodată şi ecouri româneşti care şi-au aflat acolo locul: ,un article sur le nouvel art roumain avec reproductions de Marcel Ianco, Mattis Teutsch et une traduction littérale d'un poème de Vinea" (Contimporanul, 1924, XI: 49).

În acest număr al Contimporanului (1924, XI: 48) se mai semnalează, pe scurt şi pentru prima dată, revista Zwrotnica. Kierunek: sztuka teraźniejszości [Manevră. Direcţiunea: arta prezentului] a lui Tadeusz Peiper (1891-1969) - poet, critic literar, teoretician de artă poetică, eseist, autor de romane şi jurnale, dramaturg, iniţiatorul grupării de avangardă artistică Awangarda Krakowska [Avangarda din Cracovia] (1922-1927), al cărei program a fost prezentat într-un manifest, Punkt wyjścia [Punctul de ieşire], publicat în primul număr al revistei Zwrotnica din mai 1922 care aminteşte manifestul futurist al lui Marinetti: masă-viteză-inventivitateconstrucţie fermă-economie a limbajului poetic-modernitate-disciplină intelectualămetaforă condensată-antisentimentalism.

Titlul revistei Zwrotnica mai apare în numărul 65 al Contimporanului din 15 martie 1926, la rubrica „Note, cărţi, reviste”: „A apărut în Cracovia, în editura revistei Zuvtotnika de T. Peiper Szosta Szosta? şi de J. Kurek O poveste despre Amundsen" (Contimporanul, 1926, III: 65).

De fapt, în cazul lui Peiper, este vorba despre o piesă de teatru, în două părţi, intitulată Szósta! Szósta! [Ora şase! Ora şase!], din 1925. Exemplificarea teoriei de teatru avangardist a lui Peiper, care a fost pusă pe scenă la Kalisz, abia în anul 1974, şi în cazul lui Jalu Kurek (1904-1983), O poveste despre Amundsen se adevăreşte a fi un roman autobiografico-poliţist, intitulat Kim byt Andrzej Panik? Andrzej Panik zamordowat Amundsena [Cine a fost Andrzej Panik? Andrzej Panik l-a ucis pe Amundsen], chiar din 1926, anul însemnării de la Contimporanul.

Numărul 52 al Contimporanului, din 1925, consacrat lui Constantin Brâncuşi, la rubrica „L'exposition internationale du Contimporanul” enumără toate țările care au luat parte la această expoziţie: „C'est la première exposition moderne à la quelle participent la Belgique, l'Allemagne, la Suède, l'Hongrie, la Pologne, la Serbie et la

\footnotetext{
${ }^{1}$ Intercalat, Z.H.

${ }^{2}$ Ortografia originală (Z.H.).
} 
Roumanie" (Contimporanul, 1925, II: 52), cu un succint comentariu redacţional despre prezentată artă din Polonia: „La Pologne par Zarnoverovna et Szczuca démontre l'influence du dessin linéaire et géometrique sur les moyens d'expression moderne. Ce serait quelques fois des projets de très bons vitraux [...]" (Contimporanul, 1925, II: 52).

În acelaşi număr al revistei (52/1925) se mai menţionează, pe scurt, şi revista poloneză Blok, mai precis, numărul 8-9, fiind etichetat drept „număr de artă constructivistă poloneză”.

Despre arhitectura nouă poloneză scrie Marcel Iancu în articolul Constructivism şi arhitectură, publicat în numărul 53-54 al Contimporanului, consacrat arhitecturii moderne, din anul 1925: „Constructivismul, ale cărui origini se găsesc în începuturile artei abstracte (Radikale Künstler-Zürich), s'a dezvoltat mai ales în Rusia și Polonia [...] unde câmpul de experimentare al încercărilor de artă aplicată oferea cele mai multe posibilităţi. Dorul acestor artişti de a colabora în viaţă [...] s'a esprimat cel mai elocvent în formula lor suprematistă, care se pierde într-un complect neant formal pentru a pune numai problema materialului”, terminându-şi articolul cu o reflecţie atât de adevărată cât şi banală: „Arta este o expresie reală şi generală a energiei creatoare care organizează progresul omenirii" (Contimporanul, 1925, III: 53-54).

În ziua de 15 martie 1926 Contimporanul (numărul 65) pomeneşte din nou despre revista Blok (numărul 11) cu ocazia expoziţiei internaţionale de arhitectură modernă ,ce are loc actualmente în Varşovia”:

Au luat parte la această expoziţie Franţa (G.I.A. Perret, Le Corbusier, Mallet Stevens, Lurçat), Hollanda (I.P. Oud, Ravenstein, Rietveld, V.D. Vlugt), Belgia (Victor Servranckx, V. d. Velde, Bourgeois), Germania (Glantz, Mendelsohn, Korn), Rusia (Mielnikov, Ualevicz,) şi Polonia (Zarnoverovna, Szczuka, Kozinsky, Karzewski, Syrkus Epsteju, Lech Niemojewski, Gutt, Stefanowitz, Siemiatyczach, Lachert, Szanajca). Succesul acestei demonstraţii de artă se anunţă covârşitor pentru mişcarea nouă în Polonia (Contimporanul, 1926, III: 65).

Dintre arhitecţii polonezi citaţi de către Contimporanul, care au luat parte la mai sus pomenita expoziţie de arhitectură modernă de la Varşovia din 1926, doar jumătate din numelor citate au reuşit să fie decodate fără prea mari probleme, restul fiind greu de stabilit, mai ales la nivel ortografic şi, în plus, din cauza unui amestec bizar al câtorva nume, de ex. „Syrkus Epsteju”, ceea ce înseamnă de fapt o contopire a două nume într-unul singur; în realitate, este vorba despre Szymon Syrkus (1893-1964) - arhitect, şi foarte probabil despre un pictor de origine ebraică, Henryk Epstein (1891-1944), decedat în Auschwitz. Pe această listă, în afară de Teresa Żarnowerówna, Mieczysław Szczuka şi Lech Niemojewski (1894-1952), mai cunoscuţi, apar şi alţii, mai puțin importanți, ale căror viitoare succese arhitectonice erau încă în stare latentă: Romuald Gutt (1888-1974), Bohdan Lachert (1900-1987) sau Józef Szanajca (1902-1939). Din păcate, n-am reuşit să decodăm 
numele unor alte persoane citate de revista româna: Kozinsky - ce vrea să spună, probabil, Koziński, Karzewski - din eventualul Karczewski, Stefanowitz care pare a fi în realitate Antoni Stefanowicz (1858-1929), pictor cunoscut în epoca respectivă, stabilit la Lvov. Cu toate acestea, „Siemiatyczach” aflându-se pe lista Contimporanului, ni se pare cu totul hazardat, greu de justificat alături de numele artiştilor citaţi, însemnând pur şi simplu numele unei localităţi din nord-estul Poloniei.

În numărul 68, din iulie 1926, la rubrica „Note-Cărţi-Reviste” a Contimporanului, găsim prima semnalare a revistei poloneze Praesens, organ de presă al grupării arhitecţilor şi artiştilor plastici Praesens (1926-1930), care populariza, în arhitectură, ideea de industrializare şi standardizare a construcţiilor de case pentru locuitorii fără mari venituri financiare:

Primul număr al revistei unei grupări poloneze de pictori suprematişti şi de arhitecţi tineri polonezi: L'art de nos jours est étroitement lié à l'économie de la reflexion et de la perception. Au fur et à mesure que la vie devient mécanissée et maîtrise les impressions, le besoin surgit de systématiser les formes. Les formes irrationelles et abstractes de l'art de nos jours ne sont qu'un abrégé de l'ensemble des phénomènes examinés. Colaborează într'acest bogat număr: Malewitch, Rafalowitch, Zahorska, Witkovsky, B. Elkouken, Sijkurska, Starcov, Lahert, Malinovsky, L.P. Ond, Marc onssis, Doesburg (Contimporanul, 1926, VI: 68).

În realitate, pe lista artiştilor citaţi de Contimporanul, printre cei pe care am reuşit sa-i identific se află: Kazimierz Malewicz (1879-1935), pictor şi teoretician de artă rus, de origine poloneză, reprezentantul mişcării de avangardă din Rusia, fondatorul suprematismului; Stefania Zahorska (1890-1961), critic de artă; Romuald Kamil Witkowski (1876-1950), pictor; Bruno Elkouken (1893-1968), arhitect francez, evreu de origine poloneză; Bohdan Lachert (1900-1987), arhitect; Louis Marcoussis (1878-1941), până la 1912 - Ludwik Władysław Markus, grafician, pictor, reprezentantul cubismului; Theo van Doesburg, pe numele adevărat Christian Küpper (1883-1931), pictor olandez, romancier, arhitect, teoretician de artă.

În ianuarie 1929, apare numărul 78 al Contimporanului, unde Marcel Iancu îşi prezintă articolul intitulat Arhitectura, un soi de înregistrare a noilor evenimente ce se petreceau în domeniul arhitecturii europene. $\mathrm{Cu}$ această ocazie, Iancu menționează şi „expoziţia de proiecte şi modele de arhitectură nouă din Varşovia, unde a precumpănit conducerea idei puriste ruseşti cu acel gust de uzină proletară în orice casă sau palat urban" (Contimporanul, 1929, I: 78).

Luna următoare, la 1 februarie 1929, în numărul 79, Contimporanul iar revine asupra culturii poloneze, fără însă vreo legătură cu linia avangardistă a revistei respective, de data aceasta menţionând un fapt simplu din domeniul pieţii de carte, la rubrica „Note, Cărţi \& Reviste” cu o notă a lui Romulus Dianu, intitulată Marya Kasterska şi Polonia: 
În ediţiile lui Ernest Linoux a apărut o carte fermecătoare, scrisă de o veche cunoştinţă a noastră, d-na Marya Karsterska: Légendes et contes de Podlachie, cu o prefaţă de marele ideolog catolic Louis Artus.

Această interesantă femee Marya Karsterskaa care ascunde peste o delicată percepție a lucrurilor, un sensibil şi inteligent simţ al misterelor creştine a adunat, pentru a-şi servi patria, tot ce are mai frumos spiritul şi inima polonă şi dând acestor filoane ce se continuă prin ea din profunziunea veacurilor şi a raselor, forma creaţiei personale, le-a tradus franţuzeşte într'o carte deînalt interes şi de curată desfătare. Este, spun asta pentru distinşii mei cititori, o operă căreia i se cuvine altă atenţie decât cea acordată automat muştelor de aur cari încurcă raza ochiului nostru înspre apusul civilizat.

Ştiu câtă risipă de energie manifestă Marya Kasterska pentru Polonia.

Într'o convorbire pe care am avut-o cu d-sa, am văzut-o isbucnind aproape în plâns, cu un entuziasm sublim, atânci când mi-a vorbit de patria sa, a cărei ambasadoare culturală este. Eram umilit şi deconcertat. Patriotismul acesta luminat de un întreg sistem fillosofic doctrinar pâna la Barrès, Nietzsche şi Maurras, nu bănuiam că poate lua de circomstanţă forma elegantă a unei politici de expansiune culturală ca aceea întreprinsă de buna scriitoare.

Şi nu vedeam în jurul meu pe nimeni care să-i semene în aspiraţii, şi care fără învestitura oficială să aducă pe acest tărâm servicii patriei, de o atât de însemnată şi nerăsplătită importanţă. Azi citesc cartea Maryei Kasterska. E, fără îndoială o artistă şi o diplomată în acelaş timp. Asta serveşte în timp de pace o ţară, cât o întreagă armată în răsboi. Şi nu pot trece sub tăcere acest lucru. Vă rog continuaţi lectura printre rânduri (Contimporanul, 1929, II: 79).

Am citat această notă a lui Romulus Dianu (1905-1975) în întregime pentru că ni s-a părut uimitor şi revelator chiar în ce măsură o simplă culegere de legende şi poveşti a Mariei Kasterska (1894-1969), prozatoare poloneză cunoscută în Polonia doar de un număr restrâns de specialişti, a fost în stare să-i stârnească lui Dianu, prozator, publicist apreciat, traducător şi critic muzical, atâta admiraţie şi devoţiune.

Dianu şi Kasterska s-au cunoscut în România interbelică, la Bucureşti sau poate şi la Cluj, unde s-a stabilit Maria Kasterska, căsătorită cu Petre Sergescu (18931954), matematician, istoric în filosofie matematică, membru corespondent (din 1937) al Academiei Române, membru titular (din 1943) al Academiei de Ştiinţe din România şi rectorul Politehnicii din Bucureşti.

Deşi în România, Maria Kasterska, pe lângă soțul ei, profesorul Sergescu, a dus o viaţă liniştită şi răsfăţată, foarte comodă, $i$-a fost tot timpul dor de Polonia şi, mai ales, de o regiune din nord-estul Poloniei, Podlasie, unde şi-a petrecut copilăria, pe moşia lui Bryndza-Nacki din Woroblin, administrată de tatăl ei, Maximilian. Manifestându-şi iubirea neîncetată pentru patrie, Kasterska a zăbovit de nenumărate ori în Polonia, întâlnindu-se cu tinerimea din Podlasie şi scriind la reviste poloneze Świat, Kurier Warszawski şi Tygodnik Ilustrowany, ceea ce lui Romulus Dianu i s-a părut a fi un model de iubire de patrie de dorit.

După instaurarea regimului comunist în România, soţii Sergescu au emigrat în Occident, stabilindu-se în Franţa, la Paris, unde profesorul Sergescu a murit în 1954 
şi Maria Kasterska - în 1969, fiind înmormântaţi amândoi la cimitirul Les Champeaux din Montmorency.

Primul număr al Contimporanului apare pe 3 iunie 1922. Redactor este deocamdată numai Ion Vinea, care aparţine aşa-numitei „generaţii a Marii Unirii” din 1918, un intelectual independent, deziluzionat, dezamăgit de compromiterea politică a idealului naţional. Printre colaboratori întâlnim scriitori modernişti, foşti membri ai cercului patronat de controversatul Alexandru Bogdan-Piteşti, oameni politici de stânga şi gazetari independenţi de aceeaşi orientare, critici ai politicii liberale din timpul Primului Război Mondial şi combatanţi ai revistelor socializante imediat postbelice (de ex., Chemarea). Dar linia revistei va fi una democratică, adversară politicianismului, corupţiei, inerţiei tradiţionale, xenofobiei şi antisemitismului. Contimporanul devine, în cei zece ani de existență, o importantă tribună intelectuală, un intermediar între Sburătorul, Gândirea, Viaţa românească şi cele mai radicale publicaţii avangardiste (Urmuz, unu, Integral, $75 \mathrm{HP}$ ).

Revista Contimporanul, fiind deschisă programatic la orice noutate intelectuală şi artistică de peste hotare, asigurându-se colaborarea efectivă şi inedită a scriitorilor şi artiştilor conducători ai mişcării noi din Europa, a deprovincializat într-un fel cultura română, manifestându-şi voinţa fermă de depăşire a complexului periferiei, datorită atenţiei acordate nu numai marilor culturi europene, dar şi unor idei de avangardă - toutes proportions gardées - din ţări vecine, la fel de periferice şi complexate, cum era şi cazul Poloniei din epoca respectivă.

\section{BIBLIOGRAFIE}

BARANOwicz, Z. (1979): Polska awangarda artystyczna 1918-1939. Warszawa: Wydawnictwa Artystyczne i Filmowe.

BÂRNA, N. (2003): Avangardismul literar românesc. Bucureşti: Edidura Gramar.

CERnAt, P. (2007): „Contimporanul”. Istoria unei reviste de avangardă. Bucureşti: Institutul Cultural Român.

Contimporanul. Revistă de avangardă, cu program constructivist. I. Vinea (ed.). Bucureşti. 1924, IV: 45, X: 48, XI: 49; 1925, II: 52, IV: 53-54; 1926, III: 65, VI: 68; 1928, III: 77; 1929, I: 78, II: 79 .

DuDA, G. (1997): Literatura românească de avangardă. Bucureşti: Editura Humanitas.

HANGIU, I. (2004): Diç̧ionarul presei literare româneşti (1790-2000): Bucureşti: Editura Institutului Cultural Român.

Mincu, M. (1983): Avangarda literară românească. Bucureşti: Editura Minerva.

Morar, O. (2005): Avangardismul românesc. Bucureşti: Fundaţia Culturală „Ideea Europeană”.

POP, I. (1990): Avangarda în literatura română. Bucureşti: Editura Minerva. 